\title{
Association between Obesity and COVID-19 Mortality in Peru: An Ecological Study
}

\author{
Max Carlos Ramírez-Soto * (D), Miluska Alarcón-Arroyo, Yajaira Chilcon-Vitor, Yelibeth Chirinos-Pérez, \\ Gabriela Quispe-Vargas, Kelly Solsol-Jacome and Elizabeth Quintana-Zavaleta \\ Facultad de Ciencias de la Salud, Universidad Tecnologica del Peru, 15046 Lima, Peru; \\ U18205082@utp.edu.pe (M.A.-A.); U19102232@utp.edu.pe (Y.C.-V.); U18301301@utp.edu.pe (Y.C.-P.); \\ U18305711@utp.edu.pe (G.Q.-V.); U18302765@utp.edu.pe (K.S.-J.); U19205940@utp.edu.pe (E.Q.-Z.) \\ * Correspondence: maxcrs22@gmail.com or max.ramirez@upch.pe
}

\section{check for}

updates

Citation: Ramírez-Soto, M.C.; Alarcón-Arroyo, M.; Chilcon-Vitor, Y.; Chirinos-Pérez, Y.; Quispe-Vargas, G.; Solsol-Jacome, K.; Quintana-Zavaleta, E. Association between Obesity and COVID-19 Mortality in Peru: An Ecological Study. Trop. Med. Infect. Dis. 2021, 6, 182. https://doi.org/ 10.3390 /tropicalmed6040182

Academic Editors: Peter A. Leggat, John Frean and Lucille Blumberg

Received: 12 August 2021

Accepted: 21 September 2021

Published: 7 October 2021

Publisher's Note: MDPI stays neutral with regard to jurisdictional claims in published maps and institutional affiliations.

Copyright: (c) 2021 by the authors. Licensee MDPI, Basel, Switzerland. This article is an open access article distributed under the terms and conditions of the Creative Commons Attribution (CC BY) license (https:// creativecommons.org/licenses/by/ $4.0 /)$.

\begin{abstract}
There is a gap in the epidemiological data on obesity and COVID-19 mortality in low and middle-income countries worst affected by the COVID-19 pandemic, including Peru. In this ecological study, we explored the association between body mass index (BMI), the prevalence of overweight and obesity, and the COVID-19 mortality rates in 25 Peruvian regions, adjusted for confounding factors (mean age in the region, mean income, gender balance and number of Intensive Care Unit (ICU) beds) using multiple linear regression. We retrieved secondary region-level data on the BMI average and prevalence rates of overweight and obesity in individuals aged $\geq 15$ years old, from the Peruvian National Demographics and Health Survey (ENDES 2020). COVID-19 death statistics were obtained from the National System of Deaths (SINADEF) from the Peruvian Ministry of Health and were accurate as of 3 June 2021. COVID-19 mortality rates (per 100,000 habitants) were calculated among those aged $\geq 15$ years old. During the study period, a total of 190,046 COVID-19 deaths were registered in individuals aged $\geq 15$ years in 25 Peruvian regions. There was association between the BMI $(r=0.74 ; p=0.00001)$ and obesity $(r=0.76 ; p=0.00001)$, and the COVID-19 mortality rate. Adjusted for confounding factors, only the prevalence rate of obesity was associated with COVID-19 mortality rate $(\beta=0.585 ; p=0.033)$. These findings suggest that as obesity prevalence increases, the COVID-19 mortality rates increase in the Peruvian population $\geq 15$ years. These findings can help to elucidate the high COVID-19 mortality rates in Peru.
\end{abstract}

Keywords: COVID-19; pandemic; overweight; obesity; Peru

\section{Introduction}

Overweight and obesity are global public health problems [1]. Their prevalence has increased rapidly during recent decades [2,3], and studies have shown an association between obesity and infectious diseases [4]. During the COVID-19 pandemic, studies in high-income countries have shown that obesity increases the risk for hospitalization and death among patients with COVID-19 [5,6]. Most studies included patients with COVID-19 symptoms admitted to hospital, where obesity itself and the severity of the disease increase the risk of death $[7,8]$. Avoiding this bias, one recent study showed that excess weight linearly increased the risk of severe COVID-19, leading to admission to hospital and death (body mass index $>28 \mathrm{~kg} / \mathrm{m}^{2}$ ) [9]. In other observational studies, obesity prevalence was significantly correlated with both infection and/or COVID-19 mortality [10-13]. Despite these findings, to date, there is a gap of epidemiological data on obesity and COVID-19 mortality in low- and middle-income countries.

In Latin American, Peru has been one of the worst-affected countries by the COVID-19 pandemic $[14,15]$. Despite the rapid implementation of control measures, by the end of June 2021, more than two million cases and over 190,000 deaths were confirmed, with a case fatality rate of $9.31 \%$ [16]. In addition, a study in the first months of the COVID-19 pandemic found a correlation between the prevalence of obesity and COVID-19 mortality, 
although its findings are limited [13]. Despite this, it has not been documented how COVID-19 mortality rates vary according to body mass index (BMI) and the prevalence of overweight and obesity. Here, we explored the association between body mass index (BMI), the prevalence of overweight and obesity, and COVID-19 mortality in 25 Peruvian regions, adjusted by for possible confounding factors.

\section{Materials and Methods}

\subsection{Study Design and Setting}

We performed an ecological study following the Strengthening the Reporting of Observational Studies in Epidemiology (STROBE) reporting guidelines [17]. For this study, we retrieved secondary region-level data on the BMI average and prevalence rates of overweight and obesity in individuals aged $\geq 15$ years old from the Peruvian National Demographics and Health Survey (ENDES 2020) [18]. ENDES 2020 includes a sample of 32,197 men and women aged 15 years or more, from 25 Peruvian regions (Figure 1), from January to December 2020. COVID-19 deaths were obtained from the National System of Deaths (SINADEF) from the Peruvian Ministry of Health (MINSA), accurate as of 3 June 2021 [19]. The SINADEF database records all deaths that occur in Peru and generates the death certificates and statistical reports. Death records with COVID-19 as the underlying cause of death were included in the study. Data on the mean age in the region, mean income and gender balance were retrieved obtained from the National Institute of Statistics and Informatics (INEI). The number of Intensive Care Unit (ICU) beds was obtained of App. F500.2 from at the Superintendencia Nacional de Salud, Perú (SUSALUD).

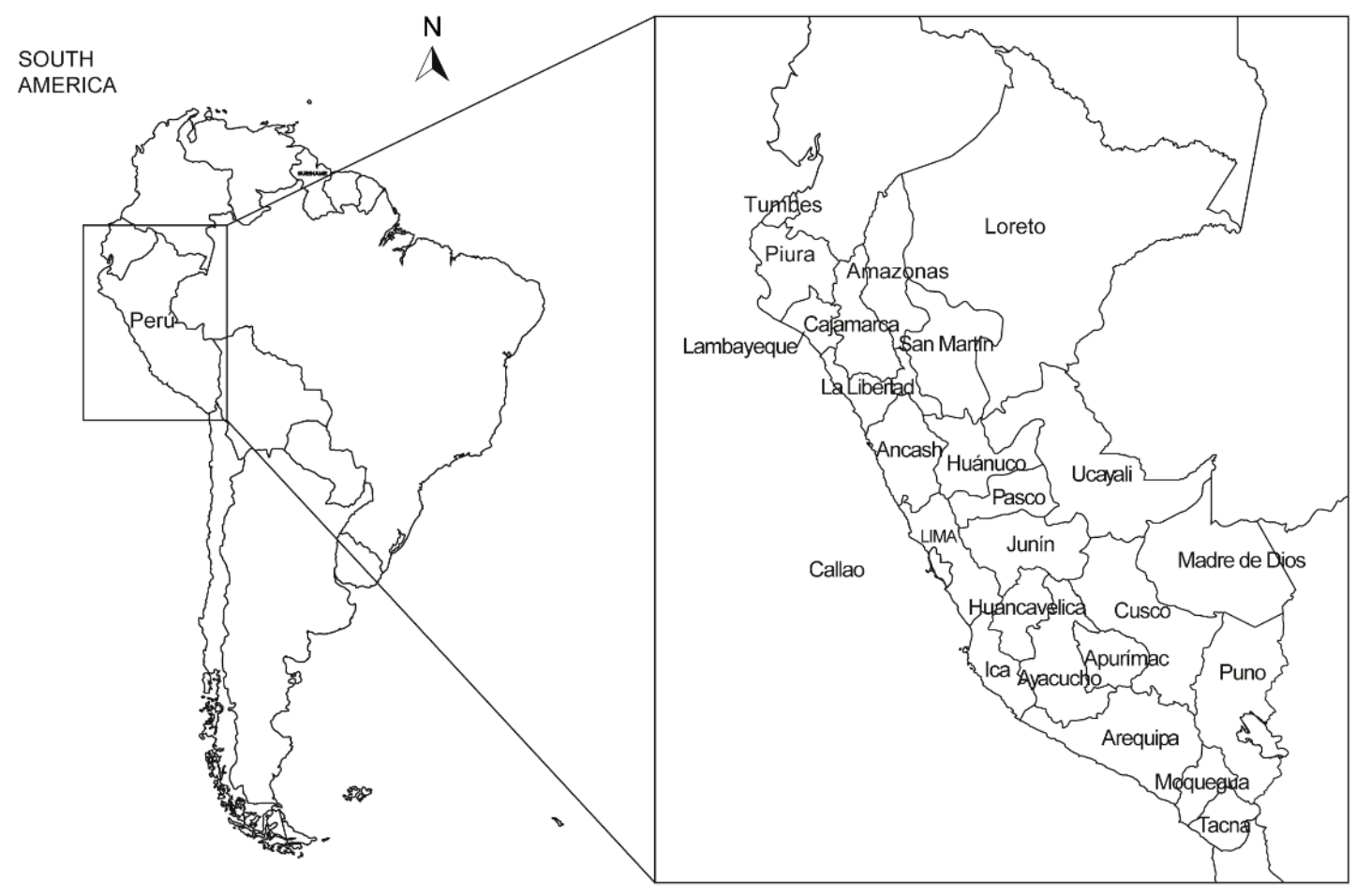

Figure 1. Location of Peru within South American.

\subsection{Statistical Analysis}

COVID-19 mortality rates (per 100,000 habitants) among those aged $\geq 15$ years old were calculated by dividing the number of COVID-19 deaths per department by the estimated population of each department. Population counts for calculating mortality rates were obtained from the INEI, Peru [20]. Spearman's test and linear regression models were used to estimate correlations between the BMI, the prevalence of overweight and obesity, and COVID-19 mortality rates. Multiple regression analysis was also used for possible 
confounding factors. $p$-values $<0.05$ were considered significant. Confounding factors included the mean age in the region (years), mean monthly income (PEN), gender balance and number of ICU beds. Statistical analyses were conducted using StataSE 16.0 Software.

This study was based on public use data that do not include personal information; therefore, it was exempt from institutional review board approval.

\section{Results}

During the study period, a total of 190,046 COVID-19 deaths were registered in individuals aged $\geq 15$ years in 25 Peruvian regions. Among the individuals aged $\geq 15$ years old, the highest prevalence rates of overweight and obesity were registered in Tacna, Moquegua, and Ica regions. The five regions with the highest COVID-19 mortality rates were Ica (1083.6 per 100,000 habitants), Callao (1071.3 per 100,000 habitants), Lima (979.9 per 100,000 habitants), Moquegua (883.3 per 100,000 habitants), and Lambayeque ( 811.4 per 100,000 habitants) (Table 1).

Table 1. BMI average, prevalence of overweight and obesity, and COVID-19 mortality rate in $\geq 15$-year-olds in 25 Peruvian regions, March 2020 to June 2021.

\begin{tabular}{|c|c|c|c|c|c|c|c|c|c|c|}
\hline Region & $\begin{array}{c}\text { BMI } \\
\left(\mathrm{kg} / \mathrm{m}^{2}\right) \\
{[18]}\end{array}$ & $\begin{array}{l}\text { Prevalence } \\
\text { of } \\
\text { Overweight } \\
\text { (\%) [18] }\end{array}$ & $\begin{array}{l}\text { Prevalence } \\
\text { of } \\
\text { Obesity } \\
(\%)[18]\end{array}$ & $\begin{array}{l}\text { COVID- } \\
19 \text { Deaths } \\
\text { [19] }\end{array}$ & $\begin{array}{c}\text { Population } \\
\text { [20] }\end{array}$ & $\begin{array}{c}\text { COVID-19 } \\
\text { Mortality } \\
\text { Rate (per } \\
100,000 \\
\text { Habitants) }\end{array}$ & $\begin{array}{l}\text { Mean } \\
\text { Age } \\
\text { (Years) }\end{array}$ & $\begin{array}{l}\text { Mean } \\
\text { Monthly } \\
\text { Income } \\
\text { (PEN) }\end{array}$ & $\begin{array}{c}\text { Gender } \\
\text { Balance } \\
\text { (Men/Women) } \\
\text { [20] }\end{array}$ & $\begin{array}{l}\text { No. } \\
\text { of } \\
\text { ICU } \\
\text { Beds }\end{array}$ \\
\hline Amazonas & 26.2 & 36.1 & 15.8 & 1135.0 & $289,802.0$ & 391.6 & 30.95 & 1014.0 & 1.07 & 19 \\
\hline Ancash & 26.9 & 35.6 & 21.8 & 6373.0 & $876,703.0$ & 726.9 & 32.36 & 1230.9 & 1.01 & 62 \\
\hline Apurimac & 25.8 & 33.2 & 14.7 & 1401.0 & $300,395.0$ & 466.4 & 29.99 & 1123.8 & 1.05 & 38 \\
\hline Arequipa & 28.0 & 36.8 & 28.8 & 8519.0 & $1,187,931.0$ & 717.1 & 32.45 & 1703.1 & 0.95 & 92 \\
\hline Ayacucho & 25.9 & 33.9 & 15.5 & 1949.0 & $464,136.0$ & 419.9 & 30.04 & 970.6 & 1.04 & 20 \\
\hline Cajamarca & 25.9 & 38.6 & 13.9 & 3839.0 & $1,016,792.0$ & 377.6 & 30.71 & 954.4 & 0.98 & 61 \\
\hline Callao & 28.4 & 35.3 & 31.8 & 9670.0 & $902,609.0$ & 1071.3 & 32.36 & 1579.6 & 0.94 & 113 \\
\hline Cusco & 26.2 & 36.6 & 16.8 & 4390.0 & $988,897.0$ & 443.9 & 30.34 & 1234.1 & 1.02 & 50 \\
\hline Huancavelica & 24.9 & 30.8 & 9.6 & 1079.0 & $236,955.0$ & 455.4 & 30.28 & 742.1 & 1.01 & 21 \\
\hline Huanuco & 26.2 & 36.9 & 15.9 & 2558.0 & $524,371.0$ & 487.8 & 30.01 & 1007.1 & 1.01 & 44 \\
\hline Ica & 28.4 & 36.5 & 33.5 & 7863.0 & $725,610.0$ & 1083.6 & 30.93 & 1507.5 & 0.99 & 84 \\
\hline Junin & 26.4 & 39.3 & 17.0 & 6570.0 & $982,199.0$ & 668.9 & 31.18 & 1206.3 & 0.98 & 77 \\
\hline $\begin{array}{c}\text { La } \\
\text { Libertad }\end{array}$ & 27.9 & 38.5 & 27.8 & 9778.0 & $1,531,668.0$ & 638.4 & 31.55 & 1307.5 & 0.97 & 96 \\
\hline Lambayeque & 27.5 & 39.5 & 25.0 & 8042.0 & $991,121.0$ & 811.4 & 32.24 & 1203.6 & 0.93 & 86 \\
\hline Lima & 28.1 & 37.0 & 28.9 & $85,748.0$ & $8,750,417.0$ & 979.9 & 33.05 & 1885.9 & 0.91 & 845 \\
\hline Loreto & 26.4 & 29.6 & 22.1 & 3977.0 & $680,927.0$ & 584.1 & 28.50 & 1231.5 & 1.08 & 52 \\
\hline $\begin{array}{l}\text { Madre de } \\
\text { Dios }\end{array}$ & 28.5 & 43.9 & 32.4 & 727.0 & $135,428.0$ & 536.8 & 27.48 & 1665.0 & 1.37 & 25 \\
\hline Moquegua & 28.7 & 37.7 & 35.8 & 1374.0 & $155,545.0$ & 883.3 & 32.85 & 1801.5 & 1.17 & 28 \\
\hline Pasco & 26.3 & 37.7 & 17.2 & 961.0 & $195,114.0$ & 492.5 & 30.12 & 1172.0 & 1.07 & 31 \\
\hline Piura & 27.2 & 34.2 & 25.0 & $11,414.0$ & $1,535,433.0$ & 743.4 & 30.42 & 1146.0 & 1.01 & 109 \\
\hline Puno & 26.8 & 37.9 & 20.4 & 3603.0 & $904,267.0$ & 398.4 & 29.72 & 876.1 & 0.96 & 42 \\
\hline $\begin{array}{c}\text { San } \\
\text { Martin }\end{array}$ & 26.4 & 36.5 & 19.9 & 2833.0 & $639,533.0$ & 443.0 & 29.89 & 1159.2 & 1.14 & 49 \\
\hline Tacna & 28.7 & 38.7 & 34.4 & 1821.0 & $303,701.0$ & 599.6 & 31.91 & 1392.3 & 1.04 & 32 \\
\hline Tumbes & 27.8 & 40.0 & 27.6 & 1489.0 & $191,850.0$ & 776.1 & 29.91 & 1264.3 & 1.20 & 17 \\
\hline Ucayali & 26.9 & 37.7 & 22.0 & 2933.0 & $416,932.0$ & 703.5 & 28.00 & 1174.4 & 1.13 & 37 \\
\hline
\end{tabular}


There was an association between BMI $(r=0.74 ; p=0.00001)$ and obesity $(r=0.76$; $p=0.00001$ ) and the COVID-19 mortality rate (per 100,000 habitants) (Figure 2A-C). Adjusted by possible confounding factors (mean age in the region, mean monthly income, gender balance and number of ICU beds), only the prevalence rate of obesity was associated with COVID-19 mortality rate $(\beta=0.585 ; p=0.033)$ (Table 2$)$. The model was statistically significant $\left(F(5,19)=8.89, p<0.0002\right.$, Adj. $\left.\mathrm{R}^{2}=0.60\right)$.

A.

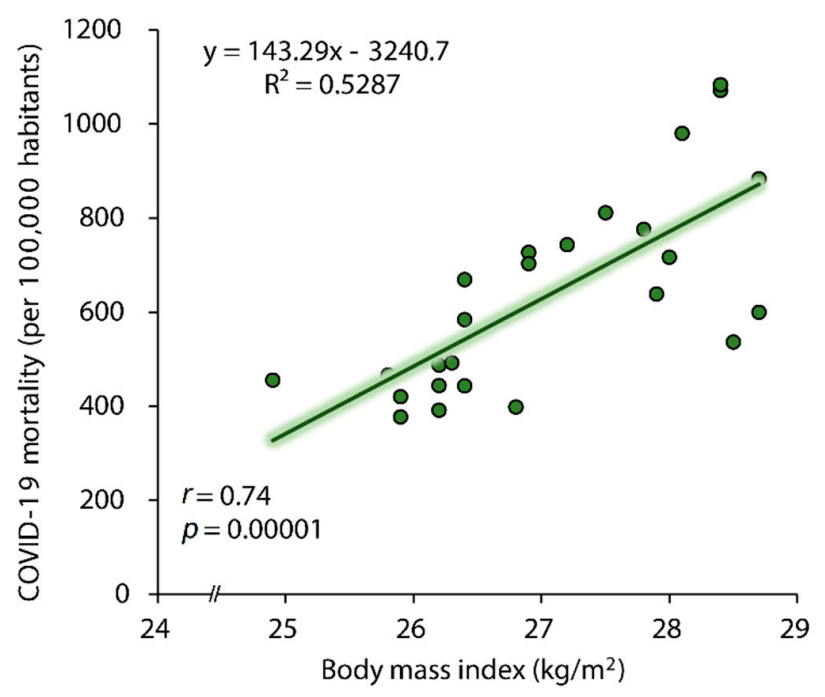

C.

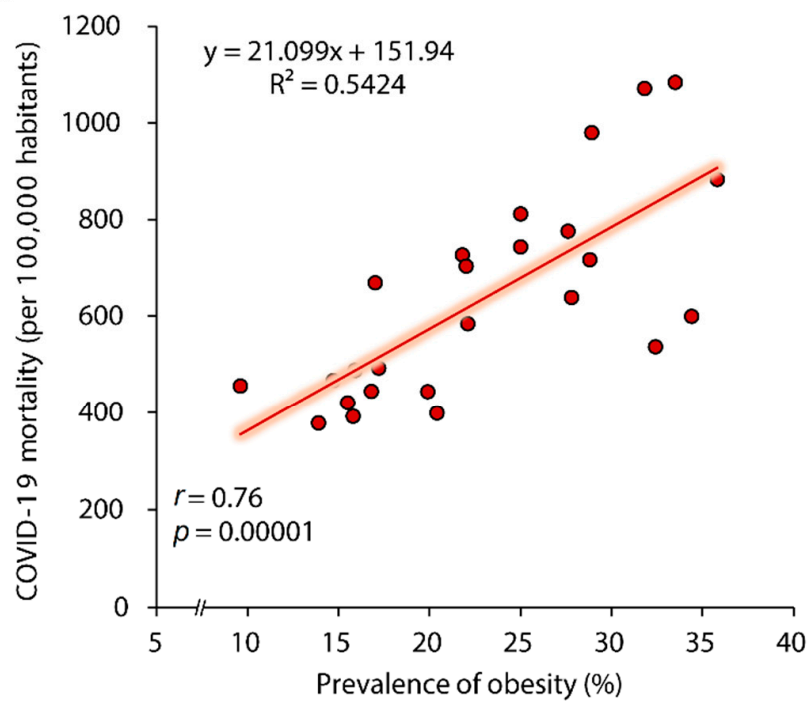

B.

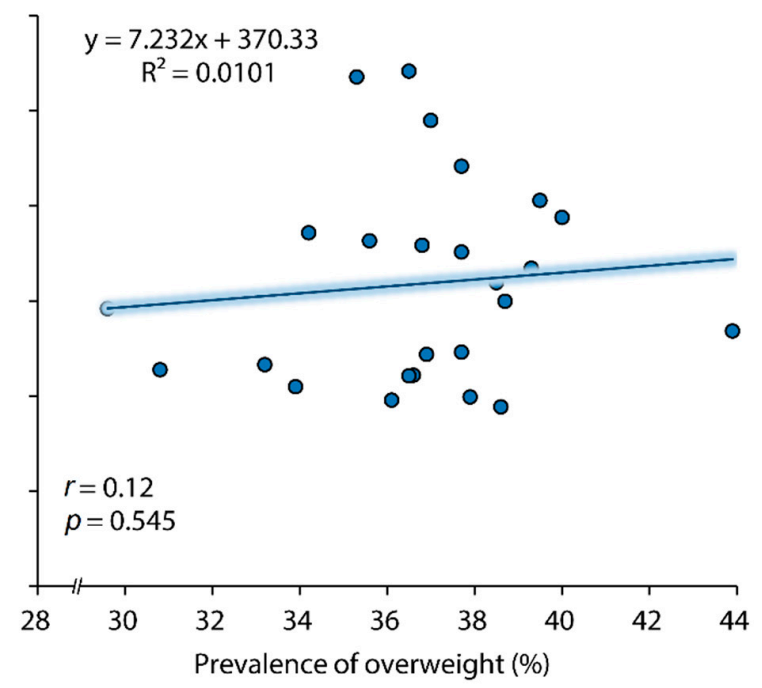

Figure 2. Correlation between body mass index (BMI) average (A), prevalence of overweight (B) and obesity (C) and mortality rates due to COVID-19 in Peru, March 2020 to June 2021. 
Table 2. Multiple regression analysis of prevalence of obesity and COVID-19 mortality adjusted.

\begin{tabular}{|c|c|c|c|c|c|}
\hline Variable & Coef. & SE & Beta & $t$ & $p$-Value \\
\hline \multicolumn{6}{|l|}{ BMI and COVID-19 mortality } \\
\hline BMI $\left(\mathrm{kg} / \mathrm{m}^{2}\right)$ & 94.49 & 51.60 & 0.479 & 1.83 & 0.083 \\
\hline Mean age in the region (years) & -5.58 & 32.62 & -0.038 & -0.17 & 0.866 \\
\hline Mean monthly income (PEN) & 0.262 & 0.23 & 0.359 & 1.10 & 0.285 \\
\hline Gender balance (men/women) & -707.0 & 482.3 & -0.336 & -1.47 & 0.159 \\
\hline No. of ICU beds & 0.028 & 0.251 & 0.021 & 0.11 & 0.911 \\
\hline \multicolumn{6}{|l|}{$\begin{array}{l}\text { Obesity and COVID-19 } \\
\text { mortality }\end{array}$} \\
\hline Prevalence of obesity (\%) & 16.76 & 7.28 & 0.585 & 2.3 & 0.033 \\
\hline Mean age in the region (years) & -2.52 & 31.2 & -0.017 & -0.08 & 0.937 \\
\hline Mean monthly income (PEN) & 0.17 & 0.23 & 0.240 & 0.75 & 0.464 \\
\hline Gender balance (men/women) & -693.81 & 462.6 & -0.330 & -1.5 & 0.15 \\
\hline No. of ICU beds & 0.08 & 0.24 & 0.068 & 0.36 & 0.72 \\
\hline
\end{tabular}

BMI: body mass index $\left(\mathrm{kg} / \mathrm{m}^{2}\right)$. ICU: Intensive Care Unit.

\section{Discussion}

During the COVID-19 pandemic, older adults and people with co-morbidities, including patients with obesity, have experienced the highest risk of COVID-19 death [6-8,21]. A previous cohort study reported that, compared with patients with a BMI of $18.5-24 \mathrm{~kg} / \mathrm{m}^{2}$, patients with BMI $\geq 40 \mathrm{~kg} / \mathrm{m}^{2}$ had a higher risk of COVID-19 death [7]. Recently, another study reported that the risk of COVID-19 death was more strongly associated with people with a BMI of more than $28 \mathrm{~kg} / \mathrm{m}^{2}$ [9]. Our findings, despite being correlational, support this observation, because in the Peruvian regions where the BMI was higher (i.e., Tacna, Moquegua and Ica), we found higher COVID-19 mortality rates. However, adjusted by possible confounding factors, there was not association between the BMI and COVID-19 mortality rates. To date, there is little evidence on the mechanisms attributable to BMI effects on COVID-19 mortality. A possible explanation is that excess weight can cause the metabolic impairment of organ functioning [22]. Other possible explanations for BMI increasing COVID-19 mortality could be associated with the severity of COVID-19, male sex, increasing age, and other factors that were not investigated in this study.

In our study, there was correlation between the prevalence of obesity and COVID19 mortality, i.e., as the obesity prevalence increased, the COVID-19 mortality rates increased in the population aged $\geq 15$ years. These findings are consistent with correlational studies which found that, as the obesity prevalence increased, the COVID-19 deaths increased [10-13]. Cohort studies and meta-analyses on the effect of excess weight on COVID-19 clinical outcomes also reported that obesity was independently associated with the severity of COVID-19 and the risk of death increased [7,8]. The increase in COVID-19 mortality in patients with obesity could be explained by associations with hypertension, diabetes, or respiratory distress syndrome [7,9]; however, to date, the mechanisms explaining the association between obesity and COVID-19 mortality remain limited. In Peru, obesity and high COVID-19 mortality also could be explained by other external factors, such as infrastructure, overload of the health system, medicines, and available intensive care unit beds $[14,15]$.

As with any observational study, the limitations of our study include its ecological design, because we used several different information sources (ENDES 2020, SINADEF, INEI, and SUSALUD); therefore, our findings could have resulted in a possible bias. In our findings, there could also have been an overestimation due to unmeasured covariates, such 
as the population density, and delayed COVID-19 death registration. On the other hand, the ecological design (group level variables) made it difficult to determine causality between the obesity and the COVID-19 mortality, i.e., we cannot make causal inference with the average characteristics of the group about individual risk. Therefore, our findings should be interpreted at the population level, not the individual-level. Finally, the ecological design is not able to account for changes that impact transmission dynamics, such as the appearance of new variants of concern or the introduction of vaccination. Despite these limitations, the main strengths of our study were the large number of deaths included ( $n=190,046$, as of June 2021) for estimating the COVID-19 mortality and the multiple regression analyses for possible confounding factors (mean age in the region, mean monthly income, gender balance and number of ICU beds), compared with a previous study that included a total of 51,789 deaths (as of July 2020) [13].

\section{Conclusions}

Our findings suggest that, as the obesity prevalence increases, the COVID-19 mortality rates increase in Peruvian populations aged $\geq 15$ years. Interventions for obesity improve weight loss; however, we cannot assure that these interventions might reduce COVID-19 mortality. In the long term, there is a need to strive towards achieving healthy weights in the Peruvian population and to decrease the risk of death from other infections in future.

Author Contributions: Conceptualization, Y.C.-V.; methodology, G.Q.-V. and M.C.R.-S.; software, Y.C.-P. and M.C.R.-S.; validation, M.A.-A. and M.C.R.-S.; formal analysis, K.S.-J., E.Q.-Z. and M.C.R.-S.; investigation, all authors; data curation, M.C.R.-S.; writing—original draft preparation, M.C.R.-S.; writing-review and editing, M.C.R.-S.; visualization, M.C.R.-S.; supervision, M.C.R.-S. All authors have read and agreed to the published version of the manuscript.

Funding: The publication of this study was funded at the Universidad Tecnologica del Peru, Lima, Peru.

Institutional Review Board Statement: Not applicable.

Informed Consent Statement: Not applicable.

Data Availability Statement: The data presented in this study are publicly available at: Demographic and Health Survey (ENDES) 2020. Noncommunicable and Communicable Diseases. 2020. Available online: https://proyectos.inei.gob.pe/endes/2020/SALUD/ENFERMEDADES_ENDES_2020.pdf (accessed on 14 September 2021); COVID-19 deaths. National System of Deaths (SINADEF). Available online: https: / / www.datosabiertos.gob.pe/dataset/fallecidos-por-covid-19-ministerio-de-saludminsa (accessed on 3 June 2021); INEI, Peruvian population: http:/ / censos2017.inei.gob.pe/ redatam/ (accessed on 3 June 2021); Daily Report on Form F500.2, app. for centralized management of the availability of Hospitalization and ICU beds at the national level and of all subsystems (Application F500.2): http:/ / portal.susalud.gob.pe/seguimiento-del-registro-de-camas-f500-2/ (accessed on 17 September 2021); Mean monthly income (PEN): https: / / www.inei.gob.pe/estadisticas/indicetematico/income/ (accessed on 17 September 2021).

Acknowledgments: The publication of this study was funded at the Universidad Tecnologica del Peru, Lima, Peru.

Conflicts of Interest: The authors declare no conflict of interest.

\section{References}

1. Blüher, M. Obesity: Global epidemiology and pathogenesis. Nat. Rev. Endocrinol. 2019, 15, 288-298. [CrossRef] [PubMed]

2. GBD 2015 Obesity Collaborators. Health Effects of Overweight and Obesity in 195 Countries over 25 Years. N. Engl. J. Med. 2017, 377, 13-27.

3. Dai, H.; Alsalhe, T.A.; Chalghaf, N.; Riccò, M.; Bragazzi, N.L.; Wu, J. The global burden of disease attributable to high body mass index in 195 countries and territories, 1990-2017: An analysis of the Global Burden of Disease Study. PLoS. Med. 2020, 17, e1003198. [CrossRef] [PubMed]

4. Huttunen, R.; Syrjänen, J. Obesity and the risk and outcome of infection. Int. J. Obes. 2013, 37, 333-340. [CrossRef] [PubMed]

5. Huang, Y.; Lu, Y.; Huang, Y.M.; Wang, M.; Ling, W.; Sui, Y.; Zhao, H.L. Obesity in patients with COVID-19: A systematic review and meta-analysis. Metabolism 2020, 113, 154378. [CrossRef] [PubMed] 
6. Hoong, C.W.S.; Hussain, I.; Aravamudan, V.M.; Phyu, E.E.; Lin, J.H.X.; Koh, H. Obesity is Associated with Poor Covid-19 Outcomes: A Systematic Review and Meta-Analysis. Horm. Metab. Res. 2021, 53, 85-93. [PubMed]

7. Tartof, S.Y.; Qian, L.; Hong, V.; Wei, R.; Nadjafi, R.F.; Fischer, H.; Li, Z.; Shaw, S.F.; Caparosa, S.L.; Nau, C.L.; et al. Obesity and mortality among patients diagnosed with COVID-19: Results from an Integrated Health Care Organization. Ann. Intern. Med. 2020, 173, 773-781. [CrossRef] [PubMed]

8. Wang, J.; Zhu, L.; Liu, L.; Zhao, X.A.; Zhang, Z.; Xue, L.; Yan, X.; Huang, S.; Li, Y.; Cheng, J.; et al. Overweight and Obesity are Risk Factors of Severe Illness in Patients with COVID-19. Obesity 2020, 28, 2049-2055. [CrossRef] [PubMed]

9. Gao, M.; Piernas, C.; Astbury, N.M.; Hippisley-Cox, J.; O’Rahilly, S.; Aveyard, P.; Jebb, S.A. Associations between body-mass index and COVID 19 severity in 6.9 million people in England: A prospective, community-based, cohort study. Lancet Diabetes Endocrinol. 2021, 9, 350-359. [CrossRef]

10. Jayawardena, R.; Jeyakumar, D.T.; Misra, A.; Hills, A.P.; Ranasinghe, P. Obesity: A potential risk factor for infection and mortality in the current COVID-19 epidemic. Diabetes Metab. Syndr. 2020, 14, 2199-2203. [CrossRef] [PubMed]

11. Ekiz, T.; Pazarl, A.C. Relationship between COVID-19 and obesity. Diabetes Metab. Syndr. 2020, 14, 761-763. [CrossRef] [PubMed]

12. Carneiro, R.A.V.D.; Hillesheim, D.; Hallal, A.L.C. Correlation of overweight condition and obesity with mortality by COVID-19 in Brazil's state capitals. Arch. Endocrinol. Metab. 2021, 65. [CrossRef]

13. Seclén, S.N.; Nunez-Robles, E.; Yovera-Aldana, M.; Arias-Chumpitaz, A. Incidence of COVID-19 infection and prevalence of diabetes, obesity and hypertension according to altitude in Peruvian population. Diabetes Res. Clin. Pract. 2020, $169,108463$. [CrossRef] [PubMed]

14. Schwalb, A.; Seas, C. The COVID-19 pandemic in Peru: What went wrong? Am. J. Trop. Med. Hyg. 2021, 104, 1176-1178. [CrossRef] [PubMed]

15. Taylor, L. Covid-19: Why Peru suffers from one of the highest excess death rates in the world. BMJ 2021, 372, n611. [CrossRef] [PubMed]

16. Peruvian Ministry of Health (MINSA). COVID-19 in Peru. Available online: https://covid19.minsa.gob.pe/ (accessed on 27 July 2021).

17. Vandenbroucke, J.P.; von Elm, E.; Altman, D.G.; Gøtzsche, P.C.; Mulrow, C.D.; Pocock, S.J.; Poole, C.; Schlesselman, J.J.; Egger, M.; STROBE Initiative. Strengthening the Reporting of Observational Studies in Epidemiology (STROBE): Explanation and elaboration. PLoS Med. 2007, 4, e297. [CrossRef] [PubMed]

18. National Institute of Statistics and Informatics (INEI); Peru-National Demographic and Health Survey (ENDES) 2020. Noncommunicable and Communicable Diseases. 2020. Available online: https://proyectos.inei.gob.pe/endes/2020/SALUD/ ENFERMEDADES_ENDES_2020.pdf (accessed on 14 September 2021).

19. Peruvian Ministry of Health (MINSA). COVID-19 deaths. National System of Deaths (SINADEF). Available online: https: / / www.datosabiertos.gob.pe/dataset/fallecidos-por-covid-19-ministerio-de-salud-minsa (accessed on 3 June 2021).

20. National Institute of Statistics and Informatics (INEI). Peruvian Population. Available online: https://www.inei.gob.pe/ estadisticas/indice-tematico/population-estimates-and-projections / (accessed on 3 June 2021).

21. Singh, A.K.; Gillies, C.L.; Singh, R.; Singh, A.; Chudasama, Y.; Coles, B.; Seidu, S.; Zaccardi, F.; Davies, M.J.; Khunti, K. Prevalence of co-morbidities and their association with mortality in patients with COVID-19: A systematic review and meta-analysis. Diabetes Obes. Metab. 2020, 22, 1915-1924. [CrossRef] [PubMed]

22. Shulman, G.I. Ectopic fat in insulin resistance, dyslipidemia, and cardiometabolic disease. N. Engl. J. Med. 2014, 371, 1131-1141. [CrossRef] [PubMed] 